\title{
EPIDEMIOLOGICAL CONSIDERATIONS OF INFLUENZA
}

\author{
Chairman: Dr H. G. Pereira \\ The role of epidemiological surveillance in the
immunoprophylaxis of influenza
}

M. S. PEREIRA

M.D.

Virus Reference Laboratory, London NW9 $5 H T$

\begin{abstract}
Summary
A considerable amount of background epidemiological information is required for a rational approach to influenza vaccination. This is discussed and illustrated with tables and figures. Examples are given of the variation of the various strains and the problem of anticipation and prediction of epidemics discussed.
\end{abstract}

THE reasons for believing influenza vaccines are necessary are based on considerable evidence accumulated over the past years on the epidemiology of influenza.

The epidemics which have occurred can be traced from the various national statistics which may be profoundly altered when the virus is circulating in the community. It is known that influenza is the disease which keeps the adult population away from their jobs and the disease which most affects the death rate.

The correlation of these two indices, morbidity and mortality, with influenza has formed the basis of surveillance with the addition more recently of information from the Royal College of General Practitioners on the assessment of influenza among patients in selected practices throughout the country confirmed by virus isolation or serology in the local Public Health Laboratory.

What has been clarified by the system of surveillance is the regularity of influenza each winter and the impact it has on the death rate.

The age incidence of deaths attributed to influenza between 1957 and 1975 is shown in Table 1. The numbers were collected from the Weekly Influenza Statements distributed by the Department of Health and Social Security during influenza epidemics and show the marked predominance of deaths in the older age groups but with a not inconsiderable number of deaths in the working population aged between 45 and 64 years. The striking feature is the small proportion of deaths in the young. Only in the first $\mathrm{H}_{2} \mathrm{~N}_{2}$ epidemic of 1957-58 was there any sizeable number of deaths in this age group.

The number of influenza virus strains examined each winter in the Virus Reference Laboratory since 1957 is shown in Table 2. There is a lack of any clear regular periodicity in either influenza A or B outbreaks and although there were nine winters in the eighteen with no significant isolations of influenza $B$, only three were without influenza $A$ and only two without both $\mathrm{A}$ and $\mathrm{B}$.

Although antigenic variation must play a significant role in the maintenance of this almost continuous winter pattern the appearance of variants has not necessarily been followed immediately by severe epidemics. The irregular detection of variants is shown in Table 3. The original $\mathrm{H}_{2} \mathrm{~N}_{2}$ virus $\mathrm{A} /$ Singapore/1/57 circulated significantly for three winters before the appearance of the first strains showing some drift away. After a winter without influenza $A$ the following one was characterized by the majority of strains behaving like the drifted strain and the disappearance of strains like the original $\mathrm{A} /$ Singapore/1/57. Thereafter a steady drift took place, never of any great degree until 1967-68 when the latest variants were joined by strains significantly altered, similar to strains isolated in Japan, A/Tokyo/67.

It might have been predicted that this strain would circulate in epidemic form the next winter but in fact a completely different virus with a novel haemagglutinin appeared, the $\mathrm{A} / \mathrm{Hong} \mathrm{Kong} / 68$ virus $\mathrm{H}_{3} \mathrm{~N}_{2}$. 
Table 1. Age distribution of influenza deaths

\begin{tabular}{|c|c|c|c|c|c|c|}
\hline & $\begin{array}{l}\text { No. of } \\
\text { weeks }\end{array}$ & $\begin{array}{l}\text { Total } \\
\text { all ages }\end{array}$ & $\begin{array}{l}\% \text { Over } \\
65\end{array}$ & $\begin{array}{l}\% \text { Over } \\
45\end{array}$ & $\begin{array}{l}\% \text { Under } \\
45\end{array}$ & Predominant virus \\
\hline $\begin{array}{l}1957-58 \\
1958-59\end{array}$ & $\begin{array}{l}35 \\
15\end{array}$ & $\begin{array}{l}4220 \\
7424\end{array}$ & $\begin{array}{l}57 \\
72\end{array}$ & $\begin{array}{l}86 \\
93\end{array}$ & $\begin{array}{r}13 \\
7\end{array}$ & $\begin{array}{l}\text { A/Singapore/57 }\left(\mathrm{H}_{2} \mathrm{~N}_{2}\right) \\
\text { A/Singapore/57 and } \\
\text { influenza } B\end{array}$ \\
\hline $1959-60$ & - & - & - & - & - & - \\
\hline $1960-61$ & 12 & 6326 & 73 & 91 & 9 & A/Singapore/57 \\
\hline $1961-62$ & 15 & 2939 & 82 & 95 & 5 & influenza B \\
\hline $1962-63$ & 11 & 2459 & 82 & 95 & 5 & A/England/63 \\
\hline $1963-64$ & - & - & - & - & - & - \\
\hline $1964-65$ & 7 & 313 & 82 & 93 & 7 & $\begin{array}{l}\text { A/England } / 64 \text { and } \\
\text { influenza } B\end{array}$ \\
\hline $1965-66$ & 11 & 2837 & 80 & 94 & 6 & $\begin{array}{l}\text { A/England/64 and } \\
\text { influenza B }\end{array}$ \\
\hline $1966-67$ & - & - & - & - & - & - \\
\hline $1967-68$ & 11 & 4234 & 89 & 98 & 2 & $\begin{array}{l}\text { A/England } / 68, \text { A/Tokyo/67 } \\
\text { and influenza B }\end{array}$ \\
\hline $\begin{array}{l}1968-69 \\
1969-70\end{array}$ & $\begin{array}{l}16 \\
12\end{array}$ & $\begin{array}{l}1077 \\
9959\end{array}$ & $\begin{array}{l}70 \\
73\end{array}$ & $\begin{array}{l}92 \\
96\end{array}$ & $\begin{array}{l}8 \\
4\end{array}$ & $\begin{array}{l}\text { A/Hong Kong/68 }\left(\mathrm{H}_{3} \mathrm{~N}_{2}\right) \\
\text { A/Hong Kong/68 and } \\
\text { influenza B }\end{array}$ \\
\hline $1970-71$ & - & - & - & - & - & - \\
\hline $1971-72$ & 11 & 1634 & 77 & 96 & 4 & A/Hong Kong/68 \\
\hline $1972-73$ & 12 & 3652 & 83 & 96 & 4 & $\begin{array}{l}\text { A/England } / 42 / 72 \text { and } \\
\text { influenza } B\end{array}$ \\
\hline $1973-74$ & 6 & 656 & 85 & 94 & 6 & $\begin{array}{l}\text { A/Port Chalmers/73 and } \\
\text { influenza B }\end{array}$ \\
\hline $1974-75$ & 15 & 1112 & 85 & 97 & 3 & $\begin{array}{l}\text { A/Port Chalmers } / 73 \text {, } \\
\text { A/Scotland } / 74 \text { and } \\
\text { intermediates }\end{array}$ \\
\hline
\end{tabular}

TABLE 2. Influenza virus strains sent to the Virus Reference Laboratory

\begin{tabular}{crrrc}
\hline Year & Total & $\begin{array}{c}\text { Influenza } \\
\text { A }\end{array}$ & $\begin{array}{c}\text { Influenza } \\
\text { B }\end{array}$ & $\begin{array}{c}\text { No. of labs } \\
\text { isolating virus }\end{array}$ \\
\hline $1957-1958$ & 604 & 604 & 0 & 13 \\
$1958-1959$ & 126 & 98 & 28 & 16 \\
$1959-1960$ & 6 & 6 & 0 & 16 \\
$1960-1961$ & 158 & 158 & 0 & 20 \\
$1961-1962$ & 68 & 1 & 67 & 25 \\
$1962-1963$ & 128 & 128 & 0 & 28 \\
$1963-1964$ & 51 & 49 & 2 & 29 \\
$1964-1965$ & 139 & 61 & 78 & 32 \\
$1965-1966$ & 214 & 107 & 107 & 36 \\
& & & & \\
$1966-1967$ & 7 & 2 & 5 & 36 \\
$1967-1968$ & 462 & 277 & 185 & 44 \\
$1968-1969$ & 886 & 881 & 5 & 44 \\
$1969-1970$ & 904 & 809 & 95 & 44 \\
$1970-1971$ & 147 & 51 & 96 & 44 \\
$1971-1972$ & 753 & 751 & 2 & 44 \\
$1972-1973$ & 1380 & 1290 & 90 & 44 \\
$1973-1974$ & 1176 & 575 & 601 & 44 \\
$1974-1975$ & 946 & 941 & 5 & 44 \\
\hline
\end{tabular}

The disparity in behaviour between the U.S.A. where the virus caused a sharp and severe epidemic and the U.K. where the virus caused a long, drawn out, smouldering epidemic has already been described but not explained; nor the reason why the U.K. was hit the next winter by a short but disastrous outbreak with a record number of deaths.
The rate of appearance of variants of the $\mathrm{H}_{3}$ virus has been considerably accelerated and the first variants were detected in the second winter of prevalence followed 4 years later by the appearance of one variant strain out of 751 examined, the A/England/42/72 virus, which became the predominant strain worldwide the next season, to be replaced by a significantly different variant, the A/Port Chalmers/ 73 , the year after, and to be joined by further variant the year after that.

This last year has seen an unusual occurrence of a strikingly mixed bag of antigenic variants circulating concurrently. The three variants and their cross reactivity is shown in Table 4.

The steady drift from the original A/Hong Kong/ 68 to the A/England/42/72 and A/Port Chalmers/73 viruses is clear with decreasing reactivity with the antiserum to the earlier virus.

During the winter of 1974-75, besides the A/Port Chalmers/ 73 virus, a new variant, which first appeared in small numbers during the previous winter in England, was detected in outbreaks in Scotland, A/Scotland/840/74. The important aspect of this variant was the poor reactivity with the $\mathrm{A} / \mathrm{Hong}$ Kong/68 and low titres with A/England/42/72 which inevitably meant that antibody left by previous infections with these two viruses was unlikely to offer much protection, and indeed antibody was found to be infrequent and of low titre. 
TABle 3. Antigenic drift in influenza $A$ viruses

\begin{tabular}{ccll}
\hline Year & $\begin{array}{c}\text { Number of } \\
\text { strains }\end{array}$ & \multicolumn{1}{c}{$\begin{array}{c}\text { Predominant } \\
\text { strain }\end{array}$} & \multicolumn{1}{c}{ Variants } \\
\hline $1957-58$ & 604 & A/Sing/57 $\left(\mathrm{H}_{2} \mathrm{~N}_{2}\right)$ & 0 \\
$1958-59$ & 98 & A/Sing/57 & 0 \\
$1959-60$ & 6 & A/Sing/57 & 0 \\
$1960-61$ & 158 & A/Sing/57 & 55 small drift to A/Eng/1/61 \\
$1961-62$ & 1 & A/Sing/57 & 0 \\
$1962-63$ & 128 & A/E/1/61 & Further drift to A/Eng/1/63 \\
$1963-64$ & 49 & A/E/1/63 & Further drift to A/Eng/12/64 \\
$1964-65$ & 61 & A/E/12/64 & 0 \\
$1965-66$ & 107 & A/E/12/64 & 0 \\
$1966-67$ & 2 & A/E/12/64 & Further drift to A/Eng/68/68 \\
$1967-68$ & 277 & A/E/68/68 & 15 strains iike A/Tokyo/67 \\
& & & 0 \\
$1968-69$ & 881 & A/HK/1/68 $\left(\mathrm{H}_{3} \mathrm{~N}_{2}\right)$ & 0 \\
$1969-70$ & 809 & A/HK/1/68 & 35 small drift to A/E/858/69 \\
$1970-71$ & 51 & A/HK/1/68 & 0 \\
$1971-72$ & 751 & A/HK/1/68 & 1 drift to A/Eng/42/72 \\
$1972-73$ & 1290 & A/E/42/72 & 0 \\
$1973-74$ & 575 & A/PC/1/73 & 11 drift to A/Eng/635/74 \\
$1974-75$ & 941 & A/PC/1/73 & 238 drift to A/Eng/635/74 \\
& & & =: A/Scot/840/74 \\
\hline
\end{tabular}

TABle 4. Cross HI tests-influenza A viruses

\begin{tabular}{|c|c|c|c|c|c|c|}
\hline \multirow[b]{2}{*}{ Antigen } & \multicolumn{6}{|c|}{ Ferret serum } \\
\hline & $\mathrm{A} / \mathrm{HK} / 68$ & $\mathrm{~A} / \mathrm{E} / 42 / 72$ & A/PC/73 & $\mathrm{A} / \mathrm{E} / 685 / 74$ & $\mathrm{~A} / \mathrm{Scot} / 840 / 74$ & A/E/459/75 \\
\hline A/Hong Kong/68 & 2560 & 1280 & 160 & 20 & 20 & 40 \\
\hline A/Eng/42/72 & 40 & 1280 & 320 & 80 & 320 & 640 \\
\hline A/Port Chalmers/73 & 20 & 640 & 640 & 160 & 160 & 640 \\
\hline A/Eng/635/74 & $<20$ & 20 & 160 & 1280 & 640 & 1280 \\
\hline A/Scot $/ 840 / 74$ & $<20$ & 80 & 160 & $\overline{640}$ & 1280 & 1280 \\
\hline A/Eng/459/75 & $<20$ & 320 & 640 & 1280 & 5120 & $>5120$ \\
\hline
\end{tabular}

Besides this variant, in the course of examining the large number of strains isolated in Britain it became clear that in addition to the two already recognized variants there was a further variant appearing in large numbers with a greater reactivity with the older strains but otherwise showing a clear difference from all the others, having drifted in a different direction. This is typified by the strain A/England/ 459/75 which was designated as 'intermediate'.

Figure 1 shows the number of strains resembling A/Scotland/74 in relation to the total number of influenza A strains examined and shows the build-up of the epidemic from the end of December, 1974 to a peak in the middle of February, 1975, and a slow decline until the end of the epidemic at the end of March. The proportions of the three variants in this epidemic are shown in Fig. 2. The total number of strains examined was 941 of which $327(35 \%)$ resembled Port Chalmers/73, $238(25 \%)$ resembled A/Scotland/73, and $376(40 \%)$ were intermediate strains.
All three strains circulated simultaneously without a predominance of any one of them. At the end of the epidemic a random collection of serum samples from the general population were examined for antibody to the three variants. It was found that $\mathrm{HI}$ antibody at a level of $1 / 20$ or greater was present in $46 \%$ to the Port Chalmers $/ 73$ virus, $50 \%$ to the intermediate strain, and $31 \%$ to the $\mathrm{A} / \mathrm{Scotland} / 74$ variant.

Influenza surveillance has provided, therefore, a reasonable basis to answering several questions:

(1) Will there be influenza next winter? It is so much more likely than not, that it should be assumed there will be.

(2) Will it be a serious epidemic? The conditions of a fairly new variant and a low proportion of people with significant levels of antibody are right for an epidemic but the factors which bring about an associated high mortality rate are not yet defined.

(3) Should we use vaccine? If we are concerned to minimize the serious consequences of influenza, 


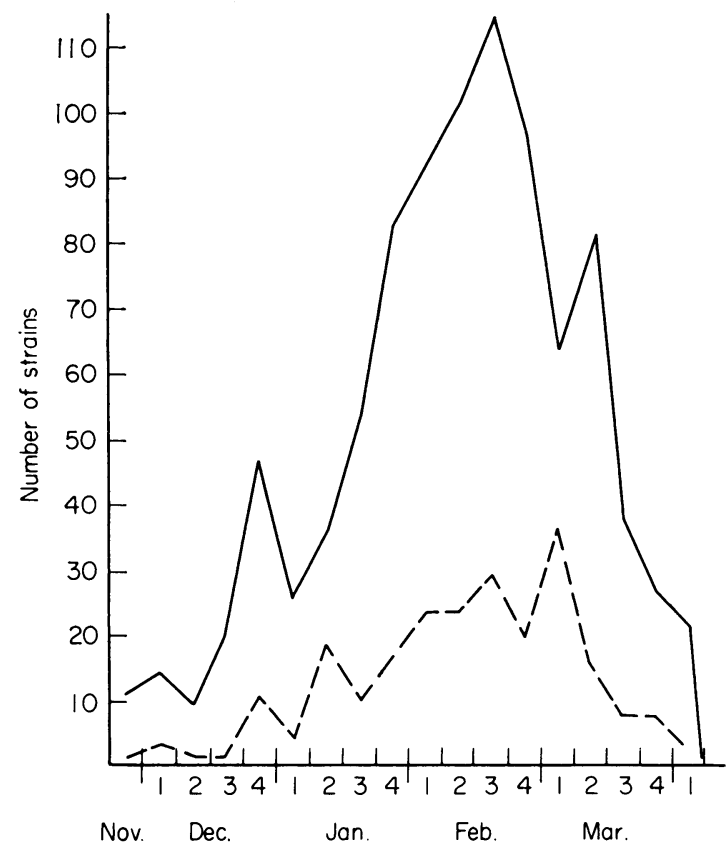

FIG. 1. 1974-75 influenza A viruses. - , Total number; -., A/Scotland/74.

people in the older age groups, particularly those with respiratory or cardiac defects, should be given vaccine. The usefulness of vaccine for other groups without a medical indication is less clear although a vaccination programme can be justified for children and adults in certain environments such as residential schools or institutions where outbreaks of influenza are both more probable and more unmanageable.

(4) When should vaccine be given? It would be prudent to give vaccine before the virus begins circu-

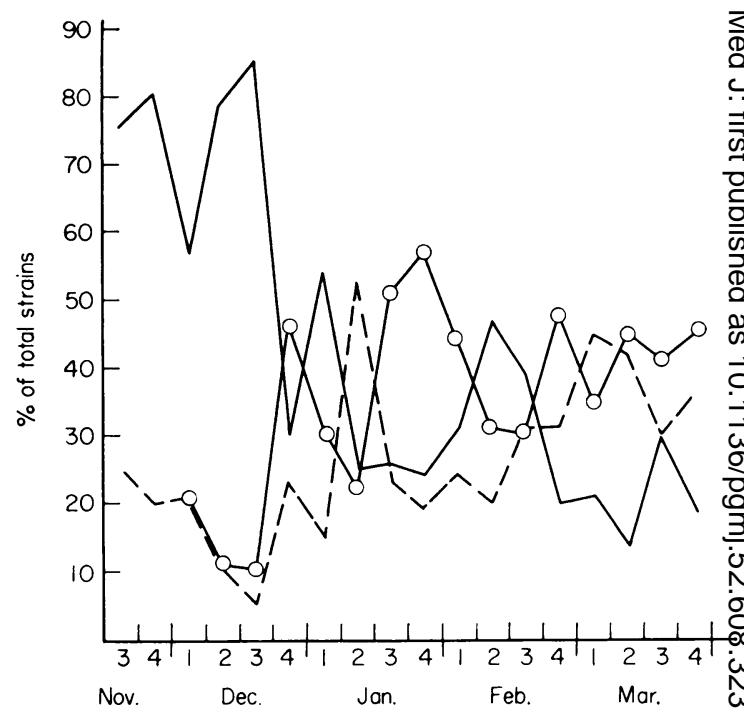

FIG. 2. 1974-75 proportion of variants of influenza A. $\mathrm{O}-\mathrm{O}$, A/Port Chalmers/73; --, intermediate; - - , A/Scotland $/ 74$.

lating in the winter. This can be as early as Novegh- $-\overrightarrow{0}$ ber. However, as we have many years' experiencespo long, drawn out, smouldering epidemics lasting 중ํㅇㅇㅡ months it should not be thought too late to protests someone at risk of serious illness at any time while the virus is known to be present.

(5) Which vaccine should be used? The relative $\frac{0}{2}$ merits of killed and live vaccines are still to be de $\overrightarrow{\vec{\pi}}$ bated but meanwhile the killed vaccines which are available have been shown to have a useful role in protection. Efforts, however, are needed to persuade doctors to use them for those people who are particularly at risk. 